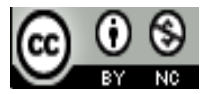

Jurnal Pendidikan Matematika Indonesia is licensed under

A Creative Commons Attribution-Non Commercial 4.0 International License.

\title{
EFEKTIVITAS PEMBELAJARAN STEM PROBLEM BASED LEARNING DITINJAU DARI DAYA JUANG DAN KEMAMPUAN PEMECAHAN MASALAH MATEMATIS MAHASISWA PGSD
}

\author{
Nurdin Arifin ${ }^{1)}$ \\ 1) Universitas Widya Gama Mahakam Samarinda, Samarinda, Indonesia \\ E-mail: nurdin.arifin91@gmail.com
}

\begin{abstract}
Abstrak. Penelitian ini bertujuan untuk mendeskripsikan dan membandingkan keefektifan antara model STEM problem based learning dan konvensional terhadap kemampuan pemecahan masalah matematis maupun terhadap daya juang mahasiswa PGSD pada matematika. Penelitian yang digunakan adalah penelitian eksperimen semu dengan desain Nonequivalent Control Group Design. Penelitian tersebut menggunakan kelas eksperimen dan kelas kontrol. Populasi penelitian ini adalah seluruh mahasiswa semester III Universitas Widya Gama Mahakam Samarinda, sedangkan sampel yang diperoleh dengan pemilihan secara acak yakni mahasiswa kelas III A dan Kelas III D. Hasil penelitian yang telah diperoleh dengan taraf signifikansi 5\% menunjukkan bahwa: 1) Terdapat perbedaan keefektifan STEM problem based learning dan model konvensional terhadap kemampuan pemecahan masalah maupun terhadap daya juang mahasiswa PGSD pada matematika; 2) Model STEM problem based learning lebih efektif daripada model konvensional terhadap kemampuan pemecahan masalah; dan 3) Model STEM problem based learning lebih efektif daripada model konvensional terhadap daya juang matematika mahasiswa PGSD
\end{abstract}

Kata kunci: STEM, PBL, Pemecahan Masalah, Daya Juang

\section{Pendahuluan}

Dinamika yang terjadi dewasa ini begitu sangat progresif. Baik dari segi teknologi yang menghadirkan artificial intelegence (AI), big data, robotic, dan internet yang berkembang pesat di era industri 4.0 dan society 5.0. Perkembangan era digital ini membantu para manusia untuk menyelesaikan permasalahan yang terjadi dalam kehidupan baik dari segi ekonomi, sosial, dan bahkan pendidikan. Pendidikan yang merupakan salah satu hal dasar yang diperoleh dalam kehidupan manusia serta yang dialami sejak dini baik dari pendidikan keluarga hingga ke tingkat pendidikan tinggi memberikan banyak perubahan pada diri manusia tersebut.

Pendidikan tinggi di Indonesia saat ini dengan kurikulum Kerangka Kualifikasi Nasional Indonesia (KKNI) yang mana tertuang dalam Peraturan Menteri Riset, Teknologi dan Pendidikan Tinggi Republik Indonesia Nomor 44 Tahun 2015 tentang Standar Nasional Pendidikan Tinggi dan di awali oleh Peraturan Presiden Republik Indonesia Nomor 8 Tahun 2012 tentang Kerangka Kualifikasi Nasional Indonesia yang mana pada hakekatnya mewujudkan pembelajaran di perguruan tinggi yang berkualitas sehingga para mahasiswa memiliki sikap, keterampilan umum, keterampilan khusus, dan pengetahuan yang mampu meneruskan perjuangan cita-cita bangsa dan kompetitif di masa Masyarakat Ekonomi ASEAN (MEA) dan global.

Menyiapkan generasi yang meneruskan cita-cita bangsa bukanlah hal yang mudah serta diperlukan upaya dari berbagai pihak. Mahasiswa yang nantinya terjun ke dunia kerja dan lapangan haruslah memiliki daya juang untuk menyelesaikan problem yang dihadapinya. Daya juang atau disebut juga Adversity Quotient (AQ) merupakan kemampuan seseorang dalam merespon dan mengatasi kesulitan dan tekanan yang terjadi dalam kehidupannya hal tersebut diutarakan oleh Stoltz (Listiawati, 2016: 296) yang juga pertama kali dicetuskannya. Hal tersebut menyiratkan bahwa setiap manusia harus mampu mengatasi masalah yang dihadapinya baik dalam kegiatan pembelajaran ataupun di lingkungan masyarakat.

Begitu pula dengan mahasiswa calon guru sekolah dasar, perlu dikembangkan dan tingkatkan daya juang mahasiswa tersebut untuk mampu memahami sumber masalah yang dihadapinya kemudian dia mampu menangani dan menyelesaikannya dengan bertanggung jawab. Berdasarkan pengamatan pada semester sebelumnya para mahasiswa PGSD Universitas Widya Gama Mahakam Samarinda masih 


\section{- - - - Jurnal Pendidikan Matematika Indonesia \\ Volum 5 Nomor 1 bulan Maret 2020 Page 31 - 38 \\ p-ISSN: 2477-5967 e-ISSN: 2477-8443}

kurangnya daya juang dalam menyelesaikan permasalahan soal cerita matematika yang diberikan, menyerah dalam menyelesaikan, bahkan tidak memiliki keyakinan dalam mengatasi permasalahan yang dihadapinya, dan akhirnya menyebabkan dirinya tidak mampu bertahan untuk menyelesaikannya ataupun tidak mampu bertanggung jawab. Padahal daya juang harus dimiliki oleh setiap manusia.

Seperti yang diutarakan oleh Stoltz (Listiawati, 2016: 297) mengutarakan empat aspek daya juang (CO2RE) yang harus dimiliki seseorang dalam mengatasi permasalahan hidupnya, yaitu (i) Control yakni keyakinan terhadap dirinya sendiri bahwa mampu mengatasi permasalahan yang dihadapinya, (ii) Origin and Ownership yakni kemampuan memahami sumber masalah yang dihadapinya dan kemungkinan yang dilakukan untuk memperbaiki situasi yang mana apakah merupakan tanggungjawabnya atau bukan, (iii) Reach yaitu kemampuan menganalisis masalah, serta sejauh mana seseorang menganggap kesulitan akan memengaruhi aspek atau kondisi lain dalam kehidupan sehari, dan (iv) Endurance yang berarti lamanya seseorang menganggap kesulitan atau problemnya akan bertahan. Kemampuan tersebut dapat ditingkatkan melalui LEAD Sequence seperti yang diutarakan oleh Stoltz (Santos, 2012: 15) bahwa mengembangkan LEAD Sequence yakni dengan: (1) Listen to one's adversity response; (2) Explore all origins and one's ownership of the result; (3) Analyze the evidence; and (4) Do something in order to help people create enduring improvements in their AQs". Lebih lanjut Stoltz (Listiawati, 2016: 297) tipe manusia yang berkaitan dengan daya juang (AQ) yaitu (i) quiter, seseorang yang mudah menyerah, (ii) camper, seseorang yang mudah puas, dan (iii) climber, seseorang yang terus berusaha mencapai tujuannya atau prestasi.

Yakoh, Chongrukasa, \& Prinyapol (2015: 285) ada 4 dimensi yang memiliki dalam AQ yakni kontrol, jangkauan kepemilikan, dan daya tahan. Hal tersebut mampu memberikan keinginan untuk bertahan dan bertanggung jawab atas kejadian yang terjadi.Selanjutnya, Francis (2000: 402) bahwa daya juang (AQ) merupakan perpaduan yang kuat antara gairah, sains, dan keprcayaan diri serta perubahan tingkah laku. Hal tersebut menjelaskan bahwa perpaduan antara kegemaran, sains, kepercayaan diri serta perubahan tingkah laku. Hal ini memberikan bagaimana pentingnya daya juang yang mampu memberikan hal kepercayaan diri dan tingkah laku. Sehingga perlunya peranan orangtua, guru/dosen sebagai pendidik untuk memberikan perhatian untuk memberikan perkembangan daya juang. Seperti yang diungkapkan Yakoh, Chongrukasa, \& Prinyapol (2015: 283) bahwa pengasuhan anak mempengaruhhi begitu banyak karakteristik psikologis anak, membuat anak peka untuk mengambil asumsi-asumsi yang mana akan mempengaruhi perkembangan daya juang (AQ) anak.

Masalah yang dihadapi dewasa ini juga semakin banyak dan harus mampu diselesaikan dengan berbagai pemecahan masalah yang tepat sasaran. Pemecahan masalah haruslah dilatih agar nantinya mahasiswa yang akan menjadi guru mampu memberikan berbagai macam solusi/penyelesaian dari berbagai pertanyaan yang dihadapinya ditengah pesatnya era teknologi. Pembelajaran dengan Sains, Teknologi,
Engineering, and Mathematics (STEM) pada abad ke-21 yang ditelah diterapkan dahulu oleh negara Amerika Serikat. Seperti yang ditarakan oleh McPherson (Green, 2014: 54) mengatakan bahwa Pengetahuan di dalam STEM akan meningkatkan keberhasilan akademik peserta didik dan menyiapakan peserta didik dalam dunia kerja. Pembelajaran dengan integrasi STEM Pembelajaran yang terintegrasi dengan STEM berpotensi untuk meningkatkan perhatian dan prestasi di dalam matematika (Stohlman, Roehirg, \& Moore (Green, 2014: 17).

John et al (2016: 34) mengutarakan bahwa pendidikan STEM merupakan gabungan sains, teknologi, teknik, dan matematika yang dimana desain pembelajaran yang bertujuan untuk menawarkan pembelajaran yang memperdalam pembelajaran STEM melalui pembelajaran berbasis proyek dan penyelidikan, dimana pembelajaran berintegrasi STEM memberikan konsep-konsep yang ada dalam sains, teknologi, teknik, dan matematika dilakukan secara bersama-sama, sehingga memungkinkan peserta didik untuk membuat koneksi lintas disiplin ilmu. Ungkapan tersebut menunjukkan bahwa pentingnya menghubungkan pembelajaran dengan konsep sains, teknologi, teknik, dan matematika sehingga dapat meningkatkan produktivitas. Seperti yang diuatarakan oleh Peri, Shih \& Sparber (Delaney \& Devereux, 2019: 219) bahwa "... STEM workers play an increasingly important role in increasing productivity and driving economic growth".

Pentingnya STEM di dalam pembelajaran di kelas, guru sebagai fasilitator dan peserta didik akan menemukan apa yang dipelajarinya sehingga akan memicu kemampuan berpikir kritis. Seperti yang diutarakan oleh McPherson (Green, 2014: 67)

"STEM education can change the paradigm in the classroom. Teachers become the facilitators of learning while students discover, explore, design, and question. Students take charge of their learning - teachers are not on the stage, but rather they set the stage with scenarios, materials, technology, and essential questions that trigger critical thinking, that are relevant to the real-world, and that engage students"

Menyiapkan guru yang mengajarkan matematika, maka guru tersebut haruslah mampu membantu peserta didik untuk mengkoneksikan antara matematika dan alam sekitar Uttendorfer (Green, 2014: 92). Lebih lanjut Uttendorfer (Green, 2014: 92) bahwa National Mathematics Advisory Panel mengungkapkan,

"Teachers must have a full understanding of the content and concepts that students are expected to learn above and below the grade levels at which they teach. They must build on students 'prior learning and prepare them for the skills and concepts they will be expected to master as they proceed in their learning of mathematics".

Mengaitkan pembelajaran matematika dalam pendidikan terintegrasi STEM, Uttendorfer (Green, 2014: 93) mengungkapkan ada 5 prinsip untuk membantu para pengajar matematika yakni: 1) Focus on inegration (fokus pada integrasi), maksudnya yakni mengaitkan permasalahan dengan keadaan yang terjadi dalam kehidupan sehingga pembelajaran menjadi bermakna; 2) Establish relevance, keterkaitan siswa 


\section{A - - - Jurnal Pendidikan Matematika Indonesia \\ Volum 5 Nomor 1 bulan Maret 2020 Page 31 - 38 \\ p-ISSN: 2477-5967 e-ISSN: 2477-8443}

jika memperoleh pengetahuan yang baru dan dapat menerapkan untuk menyelesaikan masalah; 3) Place an emphasis on $21^{\text {st }}$ century skills, kreatif membuat masalah dan proyek dalam kegiatan pembelajaran yang bukan hanya nantinya dapat membangun pengetahuan dan kemampuan matematika dan sainsnya tetapi juga membantu peserta didik mengembangkan kemampuan lainnya seperti kolaborasi, bekrja dalam tim, dan komunikasi dengan baik; 4) Challenge your students, membimbing untuk mengembangkan aktivitas peserta didik dengan memberikan masalah yang bertujuan untuk menguatkan konsep dan kemampuan siswa sehingga peserta didik menjadi ahli; 5) Mix it up, adapun maksudnya yakni pendidik menggunakan berbagai model pembelajaran dalam pembeljaran STEM. Yang dimana memberikan pertanyaan dan tantangan kepada peserta didik untuk menyelesaikan dengan mengaitkan kemampuan STEM dan memahaminya.

Pembelajaran dengan terintegrasi STEM menyiapkan mahasiswa yang nantinya menjadi guru sekolah dasar membuat pembelajaran bermakna bagi pembelajar, meningkatkan sikap, meningkatkan kemampuan tingkat tinggi dan matematika (Stohlman, Roehirg, \& Moore (Green, 2014: 29). Hal tersebut menyiratkan bahwa peran STEM dapat meningkatkan kemampuan tingkat tinggi, yang mana agar tercapainya kemampuan tersebut mahasiswa perlu mampu melakukan kegiatan pemecahan masalah. Seperti yang diutarakan Mayer \& Wittrock (Haataja et al, 2019: 2) mengutarakan bahwa pemecahan masalah merupakan proses kognitif yang mengerahkan usaha untuk menemukan solusi dari masalah yang dihadapi dan menggabungkan strategi kognitif dengan benar yang dimana seperti representasi, perencanaan, melaksanakan, dan mengatur masalahnya sendiri.

Bahkan di dalam pembelajaran matematika, selain pemecahan masalah mempunyai arti khusus, istilah tersebut mempunyai interpretasi yang berbeda, misalnya menyelesaikan soal cerita yang tidak rutin dan mengaplikasikan matematika dalam kehidupan sehari-hari. Sehingga memberikan interaksi yang kompleks antara kognitif dan metakognitif (Kazemi, Fadaee, \& Bayat (2010: 421)). Sedangkan Polya (1973) mengartikan pemecahan masalah sebagai suatu usaha mencari jalan keluar dari suatu kesulitan guna mencapai suatu tujuan yang tidak segera dapat dicapai. Apalagi bahwa pemecahan masalah merupakan salah satu dari 5 keterampilan yang dapat dikuasi. Seperti dalam Principles and Standards for School Mathematics pada tahun 2000 diungkapkan lima kemampuan yang hendaknya siswa ketahui dan dapat melakukannya, yaitu: pemecahan masalah, penalaran, komunikasi, koneksi, dan representasi (Arifin, 2018).

Berdasarkan hasil pengamatan selama satu semester di semester sebelumnya pada mata kuliah bilangan dan pengolahan data, diketahui bahwa para mahasiswa PGSD Universitas Widya Gama Mahakam Samarinda masih belum mampu memecahkan masalah dengan baik. Mahasiswa dalam menyelesaikan soal-soal belum menggunakan langkahlangkah yang terstruktur/sistematis. Begitu pula dalam menyelesaikan soal cerita yang non rutin, para mahasiswa PGSD Universitas Widya Gama Mahakam Samarinda masih belum menyelesaikan secara sistematis. Hal ini menyebabkan para mahasiswa belum maksimal dalam memecahkan permasalahan dalam soal-soal matematika.

Polya (1973) mengemukakan urutan sintaks dalam pemecahan masalah yakni: 1) Memahami masalah (Understanding the problem); 2) Merencanakan cara penyelesaian (Divising a plan); 3) Melaksanakan rencana (Carrying out the plan); 4) Melakukan pengecekan kembali terhadap semua langkah yang telah dikerjakan (Looking back). Kandemir \& Gür (2009: 1629) proses pemecahan kreatif oleh Osborn-Parnes diklasifikasikan yakni: 1)Menemukan objek yang merupakan tahap mendefinisikan area masalah, 2) Menemukan kenyataan yang merupakan fase memperoleh data; 3)Menemukan masalah yang merupakan tahap mendefinisikan masalah secara akurat; 4) Menemukan ide-ide yang merupakan tahap menggeneralisasi solusi dalam masalah; 5) Menemukan solusi yang merupakan fase menilai semua solusi yang mungkin dan membuat pilihan di antara mereka; 6) Menemukan penerimaan yang merupakan fase penerapan ideide yang dipilih dengan benar.

Salah satu upaya untuk membantu para mahasiswa dalam menambah kemampuan dalam pemecahan masalah matematis yakni dengan pembelajaran berbasis masalah. Kegiatan pembelajaran berbasis masalah atau dalam bahasa inggrisnya yakni Problem Based Learning (PBL) merupakan salah satu pembelajaran yang mengaitkan masalah dalam kehidupan nyata. Arends (Arifin, 2019) mengutarakan bahwa pembelajaran berbasis masalah merupakan pembelajaran yang mengaitkan pembelajaran dengan masalah kehidupan nyata yang membantu siswa untuk dapat terampil menyelesaikan masalah dan mengembangkan keterampilan berpikirnya.

Setiap pembelajaran memiliki sintaks, begitu pula dengan problem based learning (PBL). Menurut Tan (2009: 9) langkah dalam pembelajaran berbasis masalah ialah “ 1) menemukan masalah; 2) melakukan analisis masalah dalam pembelajaran; 3) menemukan dan melaporkan; 4) menyampaikan solusi dan refleksi; serta 5) membuat gambaran umum, evaluasi dan inttegrasi dengan pembelajaran mandiri yang mengarahkan ke tahap berikutnya Sedangkan menurut Arends (2010: 419) adapun sintaks dari problem based learning yaitu: 1) orientasi peserta didik pada masalah, 2) mengatur siswa untuk belajar, 3) membantu penyelidikan secara mandiri dan kelompok 4) mengembangkan dan menyajikan hasil kerja peserta didik, 5) menganalisis dan mengevaluasi proses penyelesaian masalah.

Peran pengajar (pendidik) dalam problem based learning ialah memberikan berbagai masalah yang autentik, fasilitator peserta didik dalam penyelidikan dan mendukung pembelajaran yang dilakukan peserta didik (Arends, 2010: 327). Hal ini menggambarkan pengajar (pendidik) sebagai fasilitator dan mediator mengorganisasi kegiatan pembelajaran.

Hal tersebut jika diterapkan dalam pembelajaran matematika akan membantu meningkatkan keterampilan para mahasiswa dalam berpikir dan akhirnya mampu memecahkan masalah. Agar nantinya para mahasiswa mampu transfer knowledge kepada para peserta didiknya ketika menjadi pendidik dan menciptakan generasi yang siap menghadapi era 
revolusi industri 4.0 dewasa ini. Oleh karena itu peneliti melakukan penelitian efektivitas pembelajaran STEM problem based learning ditijau dari daya juang dan kemampuan pemecahan masalah matematis mahasiswa PGSD Universitas Widya Gama Mahakam Samarinda

\section{METODE}

Jenis penelitian yang digunakan dalam penelitian ini adalah penelitian eksperimen semu yang dilaksanakan di Universitas Widya Gama Mahakam Samarinda. Populasi dalam penelitian ini adalah seluruh mahasiswa PGSD semester III tahun ajaran 2019/2020 pada materi geometri bangun ruang sisi datar. Teknik pengambilan dengan simple random sampling. Sampel dalam penelitian ini yaitu mengambil secara acak dua kelas dari empat kelas. Selanjutnya diperoleh kelas III A yang berjumlah 31 mahasiswa dengan pembelajaran STEM problem based learning dan kelas III D yang berjumlah 32 mahasiswa diberikan perlakuan dengan pembelajaran dengan konvensional.

Desain penelitian yang digunakan adalah pretest-posttest, nonequivalent control group design. Wiersma (1995: 144) mengutarakan bahwa desain pretest-posttest nonequivalent control group design sama dengan desain posttest only, akan tetapi pada desain subyeknya diberikan pretest. Adapun desainnya sebagai berikut

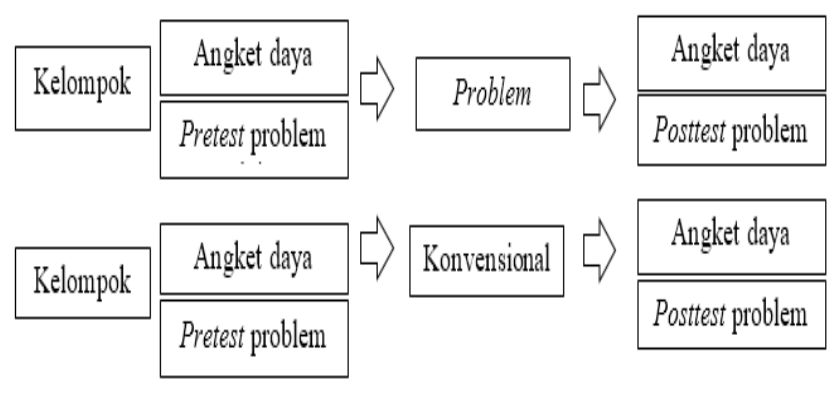

Gambar 1. Desain Penelitian

Instrumen pengumpulan data dalam penelitian ini terdiri akan instrumen tes dan nontes. Instrumen tes berupa tes kemampuan pemecahan masalah dan instrumen non-tes merupakan angket daya juang. Instrumen tes dalam penelitian ini terdiri atas soal pretest dan posttest berbentuk uraian (essay) sebanyak lima item, yang digunakan untuk mengukur kemampuan awal sebelum perlakuan dan setelah perlakuan. Instrumen non tesyakni angket daya juang digunakan untuk mengetahui bagaimana daya juang mahasiswa dalam matakuliah geometri dan pengukuran pada materi bangun ruang sisi datar, model skala daya juang yang digunakan dalam penelitian ini adalah skala Likert. Banyaknya skala Likert terdiri atas empat yaitu: sangat sesuai, sesuai, tidak sesuai, dan sangat tidak sesuai.

Validitas Instrumen tes dan angket dilakukan validitas. Validitas yang digunakan validitas isi yakni dengan cara meminta pertimbangan dan saran dari ahli (validator ahli). Instrumen tes dan non tes yang divalidasi ahli termasuk kategori valid. Pada Instrumen daya juang, dilakukan daya beda item dengan teknik korelasi product moment dari Pearson menggunakan IBM SPSS 20 menunjukkan bahwa 32 item yang ada diujikan memiliki daya beda tinggi.

Koefisien reliabilitas menggunakan Cronbach Alpha. instrumen dapat dikatakan reliabel menurut Nunnally (Ghozali,2011:48) jika nilai Cronbach Alpha > 0,70. Hasil estimasi reliabilitas disajikan sebagai berikut.

TABEL I

ESTIMASI RELIABILITAS INSTRUMEN

\begin{tabular}{lccc}
\hline & Instrumen & & $\begin{array}{c}\text { Koefisien } \\
\text { Reliabilitas }\end{array}$ \\
\hline $\begin{array}{l}\text { Kemampuan } \\
\text { (pretest) }\end{array}$ & pemecahan & masalah & 0,83 \\
$\begin{array}{l}\text { Kemampuan } \\
\text { (posttest) }\end{array}$ & pemecahan & masalah & 0,8 \\
\begin{tabular}{l} 
Daya Juang \\
\hline
\end{tabular} & & & 0,93 \\
\hline
\end{tabular}

Penentuan kriteria variabel daya juang digunakan klasifikasi berdasarkan M (rerata ideal), S (standar deviasi), $X$ (skor). Kategori yang digunakan menggunakan kriteria yang dikembangkan oleh Azwar (2014: 163). Sehingga diperoleh kategori daya juang sebagai berikut.

TABEL II KATEGORI DAYA JUANG MATEMATIKA

\begin{tabular}{cc}
\hline Skor $(\boldsymbol{X})$ & Klasifikasi \\
\hline $\boldsymbol{X}>\mathbf{1 0 4}$ & Sangat Tinggi \\
$\mathbf{8 8}<\boldsymbol{X} \leq \mathbf{1 0 4}$ & Tinggi \\
$\mathbf{7 2}<\boldsymbol{X} \leq \mathbf{8 8}$ & Sedang \\
$56<X \leq 72$ & Rendah \\
$\boldsymbol{X} \leq 56$ & Sangat Rendah \\
\hline
\end{tabular}

Teknik analisis data yang digunakan pada penelitian ini adalah uji asumsi dengan ji normalitas dan uji homogenitas. Uji normalitas menggunakan uji kolmogorov smirnov dan untuk uji homogenitas multivariat menggunakan uji Box's M dan uji homogenitas univariat menggunakan Uji Levene. Adapun kriteria keputusan yang digunakan adalah dikatakan telah memenuhi uji asumsi normalitas (berdistribusi normal) dan uji homogenitas (berdistribusi normal) jika nilai signifikansi lebih dari 0,05.

Melakukan uji hipotesis untuk membandingkan keefektifan model STEM problem based learning dengan model konvensional terhadap daya juang dan kemampuan pemecahan masalah matematika mahasiswa PGSD data dianalisis dengan $\mathrm{T}^{2}$ Hotelling. Jika terdapat perbedaan keefektifan model STEM problem based learning dengan model konvensional terhadap daya juang dan kemampuan pemecahan masalah matematika mahasiswa PGSD, akan dilakukan uji $t$ untuk menentukan model pembelajaran manakah yang lebih tinggi efeknya, baik ditinjau dari daya juang dan kemampuan pemecahan masalah matematika matematika secara terpisah. Proses analisis data dengan bantuan program IBM SPSS 20 for windows. 


\section{- - - Jurnal Pendidikan Matematika Indonesia \\ Volum 5 Nomor 1 bulan Maret 2020 Page 31 - 38 \\ p-ISSN: 2477-5967 e-ISSN: 2477-8443}

\section{HASIL DAN PEMBAHASAN}

Deskripsi data mahasiswa yang diberikan pretest dan posttest soal kemampuan pemecahan masalah matematis. Pretest diberikan sebelum diberikan perlakuan (treatment), sedangkan posttest diberikan setelah dilakukan perlakuan (treatment). Secara ringkas hasil pemecahan masalah matematis mahasiswa di sajikan sebagai berikut.

TABEL III

DESRKIPSI HASIL KEMAMPUAN PEMECAHAN MASALAH MATEMATIS

\begin{tabular}{ccccc}
\hline \multirow{2}{*}{ Deskripsi } & \multicolumn{2}{c}{ Kelas Eksperimen } & \multicolumn{2}{c}{ Kelas kontrol } \\
\cline { 2 - 5 } & pretest & posttest & pretest & Posttest \\
\hline Rata-rata & 40,45 & 79,52 & 36,83 & 76,79 \\
Standar deviasi & 8,53 & 8,37 & 9,202 & 8,79 \\
Varians & 72,79 & 70,18 & 84,69 & 77,28 \\
Nilai & 60 & 95 & 57,5 & 90 \\
maksimum & & & & \\
Nilai minimum & 28 & 65 & 20 & 55 \\
\hline
\end{tabular}

Selain data kemampuan pemecahan masalah, terdapat data daya juang terhadap matematika dideskripsikan sebagai berikut.

TABEL IV

DESRKIPSI DAYA JUANG TERHADAP MATEMATIKA

\begin{tabular}{|c|c|c|c|c|}
\hline \multirow[t]{2}{*}{ Deskripsi } & \multicolumn{2}{|c|}{ Kelas Eksperimen } & \multicolumn{2}{|c|}{ Kelas kontrol } \\
\hline & pretest & posttest & pretest & Posttest \\
\hline Rata-rata & 71,19 & 95,61 & 70,94 & 89,44 \\
\hline Skor maksimum & 116 & 116 & 116 & 116 \\
\hline Skor minimum & 57 & 85 & 58 & 59 \\
\hline SD & 14,41 & 7,98 & 13,92 & 12,60 \\
\hline
\end{tabular}

Setelah semua data terkumpul, peneliti melakukan analisis terhdap data-data yang diperoleh. Analisis data yang dilakukan berupa pengujian kondisi awal sebelum diberi perlakuan (pretest) dan kondisi akhir (posttest). Pertama yakni uji asumsi dilakukan yakni uji normalitas dengan menggunakan uji kolmogorov smirnov dengan bantuan IBM SPSS 20 for windows diperoleh nilai signifikansi dari pretest kemampuan pemecahan masalah adalah 0.068 dan nilai signifikansi dari pretest daya juang adalah 0,113 . Karena nilai signifikansinya lebih dari 0,05 , maka skor pretest hasil pengukuran hasil kemampuan pemecahan masalah matematis dan pretest daya juang mahasiswa terhadap matematika berdistribusi normal.

Kemudian untuk uji normalitas untuk hasil posttest, diperoleh nilai signifikansi dari posttest kemampuan pemecahan masalah adalah 0,438 dan nilai signifikansi dari posttest daya juang adalah 0,440 . Karena nilai signifikansinya lebih dari 0,05 maka skor posttest hasil pengukuran hasil kemampuan pemecahan masalah matematis dan posttest daya juang mahasiswa terhadap matematika berdistribusi normal.

Uji homogenitas yang digunakan yakni uji univariat dengan Levene Test yang digunakan untuk mengetahui homogen hasil kemampuan pemecahan masalah matematis (pretest dan posttest) dan daya juang mahasiswa terhadap matematika data (pretest dan posttest) secara sendiri-sendiri dan uji multivariat menggunakan Box's M test digunakan untuk mengetahui homogen hasil kemampuan pemecahan masalah matematis (pretest dan posttest) dan daya juang mahasiswa terhadap matematika data (pretest dan posttest) secara bersama-sama.

TABEL V HASIL UJI LEVENE

\begin{tabular}{lcc}
\hline & Pretest & Posttest \\
\hline $\begin{array}{l}\text { Sig. Kemampuan } \\
\text { Pemecahan masalah }\end{array}$ & 0,969 & 0,829 \\
Sig. Daya juang & 0,777 & 0,056 \\
\hline
\end{tabular}

TABEL VI

HASIL UJI BOX'S M

\begin{tabular}{lcc} 
& Pretest & Posttest \\
\hline Sig. & 0,969 & 0,051 \\
\hline
\end{tabular}

Selanjutnya pengujian hipotesis dengan uji MANOVA yakni $T^{2}$ Hotelling dilakukan pada data yang diperoleh sebelum dan setelah perlakuan (treatment). Analisis menggunakan bantuan IBM SPSS 20 for windows diperoleh sebagai berikut.

TABEL VII

HASIL $T^{2}$ HOTELLING

\begin{tabular}{lcc}
\hline & Pretest & Posttest \\
\hline F & 1,368 & 5,5 \\
Sig. & 0,268 & 0,006 \\
\hline
\end{tabular}

Pada hasil pretest bahwa nilai signifikansi sebesar 0,268. Jika dikaitkan dengan kriteria penerimaan, angka signifikansi yakni 0,268 > 0,05, maka dapat disimpulkan bahwa tidak terdapat perbedaan keefektifan STEM problem based learning dengan model konvensional terhadap daya juang dan kemampuan pemecahan masalah matematis atau dengan kata lain kondisi awal subjek penelitian pada kedua kelompok sama baik ditinjau dari daya juang dan kemampuan pemecahan masalah matematis. Ketika diberi perlakuan dan kemudian dilakukan posttest diperoleh nilai signifikansi 0,006 . Jika dikaitkan dengan kriteria penerimaaan, maka terdapat perbedaan keefektifan STEM problem based learning dengan model konvensional terhadap daya juang dan kemampuan pemecahan masalah matematis mahasiswa PGSD.

Selanjutnya untuk mengetahui keefektifan STEM problem based learning dengan model konvensional terhadap kemampuan pemecahan masalah matematis pada mahasiswa PGSD dan keefektifan STEM problem based learning dengan model konvensional terhadap kemampuan daya juang pada mahasiswa PGSD dilakukan analisis dengan menggunakan uji t dua sampel bebas. 


\section{- - - Jurnal Pendidikan Matematika Indonesia \\ Volum 5 Nomor 1 bulan Maret 2020 Page 31 - 38 \\ p-ISSN: 2477-5967 e-ISSN: 2477-8443}

TABEL VIII

HASIL UJI T DUA SAMPEL

\begin{tabular}{lc}
\hline Kelompok & Signifikansi \\
\hline STEM PBL_Konvensional - & 0,011 \\
Kemampuan Pemecahan Masalah & \\
STEM PBL_Konvensional - & 0,002 \\
Kemampuan Pemecahan Masalah & \\
\hline
\end{tabular}

Uji t dua sampel bebas. Kriteria pengujiannya adalah jika $t_{\text {hit }} \geq t_{(0,025 ; 61)}$ atau nilai signifikansi lebih kecil 0,025 maka $\boldsymbol{H}_{\mathbf{0}}$ ditolak. Pengujian hipotesis yang dilakukan untuk mengetahui apakah model STEM problem based learning lebih efektif dibandingkan dengan model konvensional terhadap kemampuan pemecahan masalah matematis, diperoleh nilai signifikansi 0,011. Uji hipotesis ini menggunakan bantuan IBM SPSS 20 for windows diperoleh nilai signifikansi $=0,011$ yang mana taraf signifikansi tersebut $<0,025$. Maka, dapat disimpulkan bahwa model STEM problem based learning lebih efektif dengan model model konvensional terhadap kemampuan pemecahan masalah matematis mahasiswa PGSD.

Selanjutnya pengujian hipotesis yang dilakukan untk mengetahui apakah model STEM problem based learning lebih efektif dengan model konvensional terhadap daya juang matematika, diperoleh nilai signifikansi 0,002. Uji hipotesis ini menggunakan bantuan IBM SPSS 20 for windows diperoleh nilai signifikansi $=0,002$ yang mana taraf signifikansi tersebut $<0,025$. Maka, dapat disimpulkan bahwa model STEM problem based learning lebih efektif dengan model model konvensional terhadap daya juang matematika pada mahasiswa PGSD.

Berdasarkan hasil analisis deskriptif yang telah dilakukan sebelumnya, pembelajaran problem based learning berdampak positif terhadap kemampuan pemecahan masalah. Hal ini dapat dilihat dari kondisi awal siswa sebelum dilakukan perlakuan bahwa kemampuan pemecahan masalah masih dinilai belum optimal. Setelah diberikan perlakuan, pada kelas model STEM problem based leaning kemampuan pemecahan masalah matematika mahasiswa mengalami peningkatan yang signifikan. Rata-rata kelas siswa mengalami peningkatan dari 40,45 menjadi 79,52.

Hasil uji T2 Hotelling menunjukkan bahwa terdapat perbedaan keefektifan STEM problem based leaning dan model konvensioanl terhadap kemampuan pemecahan masalah dan daya juang mahasiswa PGSD pada matematika. Hal ini juga diperkuat oleh perbedaan rata-rata posttest, perbedaan peningkatan kemampuan pemecahan masalah dari pretest ke posttest, perbedaan jumlah mahasiswa yang daya juang positif terhadap matematika dan perbedaan jumlah mahasiswa yang mencapai kriteria ketuntasan minimal, antara kelas eksperimen dan kelas kontrol. Pada pembelajaran yang menggunakan STEM problem based leaning para mahasiswa diminta untuk mampun mengaitkan dengan keadaan dilingkungan dimana konsep-konsep yang ada dalam sains, teknologi, teknik, dan matematika dilakukan secara bersamasama dan berusaha menyelesaikan masalah yang diberikan.
Selain itu para mahasiswa dengan menggunakan model STEM problem based leaning berusaha mencapai tujuan yakni menyelesaikan permasalahan yang dihadapinya, berusaha mengontrol, melakukan analisis tentang masalah yang dihadapinya secara bersama-sama dengan teman kelompoknya sehingga terbentuknya daya juang yang dimiliki mahasiswa yang nantinya bermanfaat buat mereka sebagai seorang guru. Seperti yang diutarakan Hemad \& Gupta (Hastuti, Sari, \& Riyadi, 2018: 2) "AQ can be useful to predict performance, motivation, empowerment, creativity, productivity, learning, energy, hope, happiness, vitality, emotional health, physical health, persistence, resilience, attitude, longevity and response to change”.

Hasil uji $t$ terhadap kemampuan pemecahan masalah matematis menunjukkan bahwa model STEM problem based leaning lebih efektif daripada model konvensional terhadap kemampuan pemecahan masalah matematis. Pembelajaran menggunakan STEM problem based leaning dan model konvensional jjika dikaitkan dengan kriteria ketuntasan yang telah ditetapkan, jumlah mahasiswa yang mencapai kriteria ketuntasan minimal, rata-rata posttest, dan peningkatan hasil belajar dari pretest ke posttest maka dapat dikatakan bahwa model STEM problem based leaning lebih efektif dari model konvensional.

Pembelajaran STEM problem based leaning mengaitkan dengan masalah yang ada dan dikaitkan dengan STEM itu sendiri sehingga menjadi lebih bermakna. Para mahasiswa diberikan kesempatan mengkonstruk pengetahuannya, mengumpulkan fakta-fakta, mengembangkan dan mempresentasikan hasil karya atau hasil pekerjaan, dan Menganalisis dan mengevaluasi proses pemecahan masalah. Sehingga para mahasiswa saling bekerja sama dalam menyelesaikan permasalahan yang mereka hadapi.

Pembelajaran dengan model konvensional dalam penelitian ini menggunakan metode ceramah dengan menggunakan alat tulis, papan tulis, dan aplikasi geogebra dalam menyampaikan materi bangun ruang. Peneliti lebih sebagai pusat pembelajaran sehingga peneliti sebagai pemberi informasi dan mahasiswa hanya siap menerima pengetahuan dari peneliti. Sehingga adanya mahasiswa yang masih belum memahami apa yang dilakukan dalam proses pembelajaran, dikarenakan mahasiswa hanya menerima konsep yang diberikan dan tidak berusaha mengkonstruk pengetahuannya. Perbedaan hal tersebut sudah memberikan akibat bahwa perbedaan keefektifan model STEM problem based learning dengan model konvensional terhadap kemampuan pemecahan masalah matematika.

Hasil uji $t$ terhadap kemampuan pemecahan masalah matematis menunjukkan bahwa model STEM problem based leaning lebih efektif dari pada model konvensional terhadap daya juang matematika. Pembelajaran menggunakan STEM problem based leaning dan model konvensional jjika dikaitkan dengan kriteria ketuntasan yang telah ditetapkan, jumlah mahasiswa yang mencapai kriteria ketuntasan minimal, rata-rata posttest, dan peningkatan daya juang matematis dari pretest ke posttest maka dapat dikatakan bahwa model STEM problem based leaning lebih efektif dari model konvensional. Hal ini juga didukung oleh berbagai penelitian. 
Pembelajaran STEM problem based leaning mengaitkan dengan masalah yang ada dan dikaitkan dengan STEM itu sendiri sehingga menjadi lebih bermakna. Para mahasiswa diberikan kesempatan mengkonstruk pengetahuannya dan pantang menyerah. Ardyanti \& Harini (2015: 34) Adversity quotient merupakan kemampuan agara mampu memperoleh jalan keluar dari masalahnya dengan mereduksi rintangan dengan mengubah pola pikirnya. Hal tersebut yang dilakukan mahasiswa ketika menyelesaikan permasalahan yang diterimanya. Masing-masing individu tiap kelompok berusaha menyelesaikan permasalahan yang diberikan hingga batas waktu yang telah ditentukan. Mereka saling bertukar ide dalam kelompoknya dan bertukar pengalaman untuk menyelesaikan permaslahannya. Hal ini poin yang penting, dikarenakan saat ini di era revolusi 4.0 perlunya kolaborasi, mengembangkan aktivitas dengan orang lain dengan berkomunikasi sehingga permasalahan dapat terselesaikan.

Pembelajaran dengan model konvensional dalam penelitian ini menggunakan metode ceramah dengan menggunakan alat tulis, papan tulis, dan aplikasi geogebra dalam menyampaikan materi bangun ruang. Peneliti lebih sebagai pusat pembelajaran sehingga peneliti sebagai pemberi informasi dan mahasiswa hanya siap menerima pengetahuan dari peneliti. Sehingga adanya mahasiswa yang masih belum memahami apa yang dilakukan dalam proses pembelajaran, dikarenakan mahasiswa hanya menerima konsep yang diberikan dan tidak berusaha mengkonstruk pengetahuannya. Mahasiswa ketika diberikan permasalahan ada yang hanya melamun, dan tidak llangsung bertindak untuk menyelesaikan. Ketika diminta untuk berdiskusi dengan teman sebelahnya para mahasiswa hanya diam saja mengerjakan sendiri tanpa berusaha diskusi dengan teman sebelahnya. Perbedaan hal tersebut sudah memberikan akibat bahwa perbedaan keefektifan model STEM problem based learning dengan model konvensional terhadap daya juang matematika mahasiswa PGSD.

\section{KESIMPULAN}

Berdasarkan hasil pengujian hipotesis dan pembahasan yang telah dikemukakan bahwa dapat disimpulkan, 1) Terdapat perbedaan keefektifan STEM problem based learning dengan model konvensional terhadap daya juang dan kemampuan pemecahan masalah matematis mahasiswa PGSD; 2) Model STEM problem based learning lebih efektif dibandingkan dengan model konvensional terhadap kemampuan pemecahan masalah matematis; dan 3) Model STEM problem based learning lebih efektif dibandingkan dengan model konvensional terhadap daya juang matematika

\section{Ucapan Terima Kasih}

Penulis mengucapkan terima kasih kepada Universitas Widya Gama Mahakam Samarinda melalui LPPM yang telah memberi bantuan dana untuk kegiatan penelitian sehingga penelitian berjalan dengan lancar.

\section{REFERENSI}

Arends, I. Richard. 2010. Learning To Teach $9^{\text {th }}$ Ed. New York: Mcgraw-Hill

Ardyanati, I. S. \& Harini, E. 2015. Hubungan Antara Adversity Quotient, Self Efficacy dan Kebiasaan Belajar Dengan Prestasi Belajar Matematika Siswa Kelas X Kecantikan SMK Negeri Se-Kecamatan Umbulharjo. Jurnal Pendidikan Matematika, Volume 3, 1: $33-44$

Arifin, N. (2018). Pengembangan Perangkat Pembelajaran Matematika Dengan Discovery Learning Berorientasikan Kemampuan Penalaran Dan Komunikasi Matematis. Pendas Mahakam: Jurnal Pendidikan Dasar, 3(2), 125-138.

Arifin, N. (2019). Upaya Meningkatkan Self-Efficacy Siswa Dalam Pembelajaran Matematika Melalui Problem Based Learning. Pendas Mahakam: Jurnal Pendidikan Dasar, 3(3), 255-266.

Azwar, S. (2014). Tes prestasi: fungsi dan pengembangan pengukuran prestasi belajar. Yogyakarta: Pustaka Pelajar Offset.

Delaney, M. Judith. \& Devereux, J. Paul. 2019. Understanding Gender Differences In STEM: Evidence From College Applications. Economics of Education, Volume 72 (2019): 219-238

Green, L. Satasha. 2014. STEM Education How To Train $21^{\text {st }}$ Century Teachers. New York: Nova Science Publishers

Ghozali, Imam. 2011. Aplikasi Analisis Multivariate dengan Program IBM SPSS 19. Semarang : Badan Penerbit Universitas Diponegoro

Haataja, E., et al. 2018. Teacher's Visual Attention When Scaffolding

Collaborative Mathematical Problem Solving. Jurnal Teaching and Teacher Education 86 (2019)

Hastuti, D. T., Sari, R. D., \& Riyadi. 2018. Student Profile With High Adversity Quotient In Math Learning. International Conference On Mathematics, Science and Education 2017 (ICMSE2017). 1-6

John, M., et al. 2016. A Formative Evaluation Of A Southeast High School Integrative Science, Technology, Engineering, and Mathematics (STEM) Academy. Technology In Society, Volume 45: 34-39

Kazemi, F., Fadaee, R. M., Bayat, S. 2010. A Subtle View to Metacognitive Aspect of Mathematical Problems Solving. International Conference on Mathematics Education Research 2010 (ICMER 2010). 420-426

Kandemir, A. Mehmet. \& Gür, Hülya. 2009. The Use of Creative Problem Solving Scenarios in Mathematics Education: Views Of Some Prospective Teachers. Procedia Social and Behavioral Sciences, Volume 1: 1628-1635

Kemenristekdikti. (2014). Peraturan Menteri Riset, Teknologi, dan Pendidikan Tinggi Republik Indonesia nomor 44 tahun 2015, tentang Standar Nasional Pendidikan Tinggi 
Listiawati, N. 2016. Persepsi Siswa Terhadap Daya Juang Mereka Serta Pola Asuh Orangtua dan Guru Di SD Berakreditasi A dan C Di Kabupaten Bantul dan Bone Bolango. Jurnal Pendidikan Dan Kebudayaan, Volume 1 (3): 295-316

Polya, G. (1973). How to Solve it: A new aspect of mathematical method. Princeton, NJ: Princeton University Press.

Presiden Republik Indonesia. (2012). Peraturan Presiden Republik Indonesia nomor 8 Tahun 2012, tentang Kerangka Kualifikasi Nasional Indonesia.

Santos, J. C. M. 2012. Assessing The Effectiveness of The Adapted Adversity Quotient Program In A Special Education School. Journal of Arts, Science \& Commerce, Volume 3, 4(2): 13-23

Tan, O.S. (Ed). 2009. Problem Base Learning and Creativity. Singapore: Cengange Learning Asia

Yakoh, M., Chongrukasa, D., * Prinyapol, P. 2015. Parenting Styles and Adversity Quotient Of Youth At Pattani Foster Home. Procedia Social and Behavioral Sciences, Volume 205, 282-286

Wiersma, W (1995). Research Methods In Education. $6^{\text {th }}$ Editions, Needham Heights, Massachusetts 02194: Allyn and Bacon, A Simon and Schuster Company. 